\title{
Comparative sensory evaluation of agidi made from hungry rice (Acha) (Digitaria exilis) and corn (Zea mays).
}

\section{Evaluación sensorial comparativa de agidi a base de arroz fonio (Acha) (Digitaria exilis) y maíz (Zea mays).}

Agomoh-Adeoye, Queen Chisom. ${ }^{1, *}$; David Humble Chika ${ }^{1}$ and Ezenwa, Happiness Chidinma. ${ }^{2}$

\author{
${ }^{1}$ Department of Home and Rural Economics. Federal College of Agriculture, Ishiagu \\ Ebonyi State. \\ ${ }^{2}$ Department of Human Nutrition and Dietetics, Michael Okpara University of Agriculture, \\ Umudike. Abia State. \\ * Corresponding author: pastorchisom5545@gmail.com or \\ pastorchisommfm@yahoo.com
}

\section{ABSTRACT}

This work evaluated the Comparative sensory properties of agidi made from hungry rice (Acha/ Digitaria exilis) and maize (Zea mays)". The production of hungry rice and maize were made up of the following recipe: $1200 \mathrm{~g}$ hungry rice, $300 \mathrm{~g}$ of chewable cow bone, 14 medium fresh tomatoe balls, 6 medium balls of onions, pepper to taste, curry powder, 4 cubes of maggi (seasoning), $200 \mathrm{~g}$ of crayfish, and $240 \mathrm{ml}$ of vegetable of oil and plantain leaves. Data was collected through sensory evaluation, as well as descriptive statistics for data analysis. Based on the research carried out on hungry rice agidi, the responses on the appearance, taste, texture, and generally acceptability of $A G 1$ are as follows $33.33 \%, 38.89 \%, 30.56 \%$ and $16.67 \%$ where AG 2 are; $16.67 \%, 16.67 \%, 19.44 \%$ and $13.89 \%$ respectively. Despite higher percentages to AG 1 produced from corn, AG 2 which is produced from hungry rice should be taken as main and staple food because of its nutritional benefits. From the results, the AG2 agidi was not poorly scored. Hence, more emphasis should be made on both meals as it is well known that in this part of the country and world, we have limited food options.

Keywords: Agidi, hungry rice, nutraceutical properties, staple diet, acha.

\section{RESUMEN}

Este trabajo evaluó las propiedades sensoriales comparativas de agidi hecho de arroz hambriento (Acha / Digitaria exilis) y maíz (Zea mays). La producción de arroz y maíz hambrientos se compone de la siguiente receta: $1200 \mathrm{~g}$ de arroz hambriento, $300 \mathrm{~g}$ de hueso 
de vaca masticable, 14 bolas medianas de tomate fresco, 6 bolas medianas de cebolla, pimienta al gusto, curry en polvo, 4 cubos de maggi (condimento), $200 \mathrm{~g}$ de cangrejo de río y $240 \mathrm{ml}$ de vegetales de aceite y hojas de plátano. Los datos fueron recolectados a través de la evaluación sensorial, así como estadísticas descriptivas para el análisis de datos. Con base en la investigación llevada a cabo con agidi de arroz hambriento, las respuestas sobre la apariencia, el sabor, la textura y la aceptabilidad general de AG 1 son las siguientes 33.33\%, $38.89 \%$, 30.56\% y $16.67 \%$ donde AG 2 es; $16.67 \%, 16.67 \%, 19.44 \%$ y $13.89 \%$ respectivamente. A pesar de los porcentajes más altos de AG 1 producidos a partir del maíz, el AG 2 que se produce a partir del arroz hambriento debe tomarse como alimento principal y básico debido a sus beneficios nutricionales. A partir de los resultados, el agidi AG2 no fue mal puntuado. Por lo tanto, se debe hacer más hincapié en ambas comidas, ya que es bien sabido que en esta parte del país y del mundo, tenemos opciones limitadas de alimentos.

Palabras clave: Agidi, arroz fonio, propiedades nutraceuticas, dieta básica, Acha

\section{INTRODUCTION}

The worlds continue to depend and receive sustenance from grain crop, (Conkin and Stillwell, 2007). Including the continent of African (Tailor, 2007). An increasing world population necessitates high production of grains to cater for the food needs of the masses resulting in the replacement of Agriculture with Agric- commerce in most part of the world. This fact is resulting in shift from non- conventional to commercial cereals crops. However, traditional cereal like sorghum (Rooney and Awika, 2008), millet, Acha (White Fonio) Iburu (blach fonio), maize and rice still constitute the staple diet from human consumption and play an essential role in providing not just foods but healthy food for the poorest populations and regions.

The consumption of hungry rice (acha) like in tuwo, gweta, acha jollof etc. should no longer be regarded as coping strategies for increasing household food security considering the high comparative cost of the traditional cereal in the area of production. It is believed that acha may have nutraceutical properties (A nutrient or food believed to have health promoting or disease preventing properties as it is used in some area for managing diabetes). Value addition and exploitation of fonio, in the development of health or specialty food like acha- bread, biscuit, cookies sough, traditional drinks, non fermented steamed sand graduated dumping products are graining interest (Balde et al., 2008).

These grains may also contribute in addressing some very relevant challenges in today's formulation both functionality and health perspectives. The constraints of low yield is receiving 
attraction in cereal breeding programmes which may give rise to a new generation of health cereal grain in future.

It is also a nutritious food plant which is a good source of carbohydrate, B vitamins, (Pantothenic acid- B5, Niacin- B3m riboflavin and thiamine- B1), folic acid, vitamin A and C, potassium, chromium, selenium, zinc, phosphorus, magnesium and many others. Corn oil is very healthy and good for the heart (Williams, 2004; Ibrahim, 2008).

It has become a subject of concern that the only widely known agidi domestically and commercially produced has remained the conventional corn starch produced one. Hence, there is an increasingly need to seek an alternative in the production line of some certain snacks to make room for varieties and new inventions.

The result of this study will be of importance to those who have special preferences for agidi by providing them with an alternative product. The general objective of this study was to produce and evaluate the sensory properties of agidi using hungry rice flour (acha), evaluate the degree of the general acceptance of the meal, and compare it with that of the conventional agidi made from corn flour.

\section{MATERIALS AND METHODS}

Material collection: the materials used were purchased from a local market in Ishiagu community, Ivo L.G.A. of Ebonyi State.

Methods of processing of raw materials: hungry rice was measured $(1200 \mathrm{~g})$, picked to remove stones, washed, soaked in water for four hours, milled into slurry and sifted. Chewable cow bones were measured $(300 \mathrm{~g})$. Onions were peeled, washed and sliced.

Recipe for hungry rice agidi: hungry rice $-1200 \mathrm{~g}$, soft chewable cow bone $-300 \mathrm{~g}$, medium fresh tomatoes -14 , medium onions balls -6 , pepper to taste, curry powder - $1 / 2$ tsp, maggi (seasoning) cubes -4 , salt - $1 / 2$ tsp, crayfish - 1 cup, vegetable oil $-200 \mathrm{ml}$, water $-300 \mathrm{mls}$ and plantain leaves to wrap.

Agidi Preparation: hungry rice slurry was poured into a pot, with the stew mixed very well to taste. The pot was put on fire then stirred continuously to avoid burning or 'seeding' of the meal, until it was cooked like the conventional agidi from corn starch. Water was added bit by bit. This is because, that was the best way to get a good result (Ozoemena, 2008).

Procedures for the agidi stew: A) Soft bones were put in a pot after washing; the chopped onions, salt, magi and pepper were added. B) Placed on top of the heat to cook before water was added to it. C) Water was poured on the same level as the bones and allowed to cook. D) The pot was removed and placed aside; another pot for frying was placed on heat. E) The fresh tomatoes were added and stirred all to dry well. F) The pepper, crayfish, magi and curry powder 
were added. G) All were allowed to boil and water was added to the stew $\mathrm{H}$ ) The stew was covered to simmer then set aside for later

Procedure for the agidi made from maize and hungry rice: A) The pot was placed on the stove with the slurries. B) The stew was poured into the hungry rice or corn slurry stirring at the same time till it started to thicken and got cooked. C) Stirring continuously until it was completely solid. D) The agidi was dished into the plantain leaves and bones were added and wrapped up. E) They were placed on the kitchen counter to cool down to a comfortable temperature and then served warm.

Sensory evaluation: thirty six (36) panels of judges were randomly selected from the Federal College of Agriculture, Ishiagu, Ebonyi State. The samples of the meals were set. Clean drinking water of room temperature was kept for rinsing of mouth to the judges after each taste, the attributes evaluated were appearance, taste, texture, and overall acceptability on a six point hedonic scale was adopted as the data collection instrument in the study.

AG1- Agidi made of corn flour $100 \%$

AG2 - Agidi made from hungry rice $100 \%$

Method of Data Analysis: data collected were analyzed with the use of descriptive statistics (Frequency table and percentage).

\section{RESULTS AND DISCUSSION}

Table 1 presented the highest percentage of the responses to appearance of the AG 1 (33.33\%) where AG 2 is $16.67 \%$ respectively. From the analysis, it is evident that more of the respondents (33.33\%) admitted that AG 1 (corn flour) has an excellent appearance. Table 2 presented the highest percentage of the responses to taste of the AG 1 (38.89\%) where AG 2 is $16.67 \%$ respectively. It is also evident here that the judges preferred the taste of the AG1 to $A G 2$. The reason for this could also be as a result of their familiarity with corn meal taste. Table 3 presented the highest percentage of the responses to texture of the agidi 1 (30.54\%) where AG 2 is 19.44\% respectively. From the result of the texture is also discovered that AG 1 was preferred to the AG2 which is a new meal about to be introduced. Where, Table 4 presented the highest percentages of the respondents in overall acceptability of the agidi 1 (16.67\%) where 2 is $13.89 \%$ respectively. The higher proportion of $16.67 \%$ showed that agidi 1 (corn flour) was excellent in general acceptability while a lower proportion of $13.89 \%$ showed that agidi 2 (hungry rice) was excellent also. However, the overall acceptability of the judges towards the dishes prepared with corn flour and hungry rice, indicated that almost $(16.67 \%$ and $13.89 \%$ ) all the respondents were highly impressed with the foods. 
Finally, the respondents at large, generally accepted agidi 1 (corn flour) in table 4 more than agidi 2 (hungry rice). This is not surprising as the respondents have showed more likeness for the appearance, tastes, and texture in agidi 1 (corn flour) made from corn starch. The reason could because they are more familiar with corn meal (AG1) than the hungry rice meal (AG2) (Elkalifa and Bernhardt, 2010).

Although, there was appreciable responses to the AG2 which could indicate a better acceptance with time and availability of the meal.

Table 1: Distribution of the responses based on the appearance of agidi.

\begin{tabular}{lcccc}
\hline Sample & \multicolumn{2}{c}{ AG1 } & \multicolumn{2}{c}{ AG2 } \\
\hline Scale & Frequency & Percentage & Frequency & Percentage \\
Excellent & 12 & 33.33 & 6 & 16.67 \\
Very good & 6 & 16.67 & 8 & 22.22 \\
Good & 6 & 16.67 & 1 & 2.78 \\
Fair & 5 & 13.80 & 6 & 16.76 \\
Poor & 6 & 16.67 & 8 & 22.22 \\
Very Poor & 0 & 0.00 & 7 & 19.44 \\
Total & 36 & 100.00 & 36 & 100.00 \\
\hline
\end{tabular}

Table 2: Distribution of the responses based on the Taste of the agidi

\begin{tabular}{lcccc}
\hline Sample & \multicolumn{2}{c}{ AG1 } & \multicolumn{3}{c}{ AG2 } \\
\hline Scale & Frequency & Percentage & Frequency & Percentage \\
Excellent & 14 & 38.89 & 6 & 16.67 \\
Very good & 5 & 13.80 & 5 & 13.80 \\
Good & 2 & 5.56 & 5 & 13.80 \\
Fair & 7 & 19.44 & 4 & 11.11 \\
Poor & 6 & 16.67 & 12 & 13.33 \\
Very Poor & 1 & 2.78 & 4 & 11.11 \\
Total & 36 & 100.00 & 36 & 100.00 \\
\hline
\end{tabular}


Sustainability, Agri, Food and Environmental Research, (ISSN: 0719-3726), 8(3), 2020: 243-249 http://dx.doi.org/10.7770/safer-VONO-art1838

Table 3: Distribution of the responses based on the Texture of the agidi.

\begin{tabular}{lcccc}
\hline Sample & \multicolumn{2}{c}{ AG1 } & \multicolumn{3}{c}{ AG2 } \\
\hline Scale & Frequency & Percentage & Frequency & Percentage \\
Excellent & 11 & 30.56 & 7 & 19.44 \\
Very good & 7 & 19.44 & 5 & 13.8 \\
Good & 7 & 19.44 & 8 & 22.22 \\
Fair & 1 & 2.78 & 1 & 2.78 \\
Poor & 6 & 16.67 & 6 & 16.67 \\
Very Poor & 4 & 11.11 & 3 & 8.33 \\
Total & 36 & 100.00 & 36 & 100.00 \\
\hline
\end{tabular}

Table 4: Distribution of the responses based on the overall acceptability of the agidi

\begin{tabular}{lcccc}
\hline Sample & \multicolumn{3}{c}{ AG1 } & \multicolumn{3}{c}{ AG2 } \\
\hline Scale & Frequency & Percentage & Frequency & Percentage \\
Excellent & 6 & 16.67 & 5 & 13.89 \\
Very good & 10 & 27.78 & 7 & 19.44 \\
Good & 5 & 13.89 & 8 & 22.22 \\
Fair & 6 & 16.67 & 1 & 2.78 \\
Poor & 3 & 8.33 & 5 & 13.89 \\
Very Poor & 5 & 13.89 & 7 & 19.44 \\
Total & 36 & 100.00 & 36 & 100.00 \\
\hline
\end{tabular}

Despite their acquaintance with the corn meal ( $A G 1)$, there is still comparable scores for AG2 (Addo and Akeredolu, 2005; Adeoye-Agomoh and Ezenwa, 2015). They were not very bad for a fresh meal about to be introduced.

Based on this study the following recommendations were made; 1 ) The awareness of the dish should be made known to many people so that they can always go for it. 2) The agidi 2 which is made from acha (hungry rice) should be introduced in the market to enlighten the people of it and importance. 3) More study should be made to fortify the meal. 


\section{REFERENCES}

Addo, A.A. and Akeredolu, I.A. 2005. Organoleptic and objective evaluation of pearl milletconophor weaning mix. Nigerian Journal of Nutrition Science, 26, 13-18.

Adeoye-Agomoh, Q.C \& Ezenwa, H.C. 2015. Evaluation of Blended Cooking Banana (Musa spp) and Soybean (Glycinemax (L.) Merrill) as Food Complement for Infants. Scientific Journal of Business and Management, (Special Issue) 3, 26-29.

Balde et al., 2008. Hungry rice (Fonio): A Neglected Cereal crop, NAQAS Newsletter. 6(4):45.www.google.com. (retrieved:23/11/2018) In: Agu, H.O, Ezeh, G.C., Jideani, A.I.O 2014. Quality Assessment of acha-based biscuit improved with bambaa nutand unripe plantain. African Journal of Food. Academicjournals.org

Conklin I.A. 2007. Digitaria exilis (acha/ fonio), Digitaria Iburu (Iburu/ fonio) and Eluesine coracana (Tamba/ finger millet)- Non conventional cereal grains with potentials. Scientific Research and Essays, 7, 3834-3843.

Elkalifa, A.E.O., and Bernhardt, R. 2010. Food Chemistry. Influence of grain germination on functional properties of sorghum flour. Food Chemistry 121, 387-392.

Ibrahim, A. 2008. Status of acha (hungry rice) production in Kaduna state. Paper presented at National Acha Stakeholder Workshop. 10-11 march, 2003.

Ozoemena, S. N. 2008. Study on the production practices of acha (Digitaria exilis Kippis Stapf) in Nigeria. Science Forum, 4, 106-113.

Roodeny, C. K. 2008. Production frontiers and productive efficiency. In Fried, A O., Lovell, A . K., and Schmidt, S.S., Eidtors, The measurement of productive efficiency, chapter 1 , pages 3-67. Oxford University press.

Taylor, R. D. 2007. Baking performance of wheat, fonio and cowpea flours. Abstract research programs on cowpeas. Dept of food science and technology, University of Georgia, 1109 experiment Street, Griffin, GA 30223.

Received: 23th November 2018; Accepted: 02th January 2020; First distribution: 31th February 2020; Final publication: 01th September 2020. 